\title{
Research on the Pricing of Supply Chain Finance Instruments
}

\author{
Yu Cheng ${ }^{a}$, Zihui Li ${ }^{b}$ \\ School of Economics and Management, Harbin University, Harbin 150086, China \\ acj7028@163.com, ${ }^{b}$ zihuili@yahoo.com
}

Keywords: Relationship-based Loans, Supply Chain Finance, Pricing of Loans.

Abstract: The scientific pricing of supply chain finance instruments is related to the improvement of the future core competitiveness of commercial banks and the further exploration of market potential. By using the pricing method of relationship-based loans for reference, this paper starts from the perspective of long-term cooperation between commercial banks and enterprises, considers the excess economic profits that may be generated by multiple sales of products, discounts the profits of enterprises currently in the supply chain by adopting a uniform distribution method, and then adds the present value to the pricing of supply chain finance instruments to develop a more favorable price. This paper also provides advice for commercial banks on how to increase market share in supply chain finance services.

\section{Introduction}

With the full implementation of China's interest rate liberalization, commercial banks are facing an increasingly fierce competition. The net interest rate spread is narrowing, and so is the profit margin. At the same time, the phenomenon of "disintermediation" is also becoming more serious. Therefore, to accelerate business innovation and to find new ways to boost profit have become an urgent task for commercial banks. Supply chain finance, as an important line of business that commercial banks urgently need to enter, has strong market potential and attracts many commercial banks to try and expand. Taking accounts receivable as an example, according to the "2015 Report of Chinese Enterprise Credit Risk Condition”, credit salehas become the most important transaction method among enterprises, and the ratio of credit sale has increased from $54.1 \%$ in 2007 to $89.6 \%$ in 2015. And the scaleof credit and the amount of days credits are given are both increasing. According to estimates by authoritative organizations, the current accounts receivable of various types of enterprises in China are more than 26 trillion yuan. If commercial banks can make full use of these accounts receivable, carry out supply chain finance services, and solve the liquidity problem of small and medium-sized enterprises (SMEs) in the supply chain, they will not only revitalize these assets, but also bring themselves huge business opportunities. Faced with the potential of the supply chain finance, if commercial banks choose todevelop the supply chain finance services and to find new way 
to generate profit, the price of supply chain finance instrument must be reasonably set.

\section{Pricing of Relationship-Based Loan and Supply Chain Finance Instruments}

Boot, Thakor (1995) gave the definition of relation-based loans, and believed that credit loans meet the following three conditions are relation-based loans: Firstly, the related bank obtains private information, rather than easily obtained public information, about the enterprise; Secondly, the private information is obtained by long-term cooperation with enterprises providing a variety of financial services; Thirdly, the private information is within the bank and is not available to outsiders. It can be seen that the relationship-based loan is a loan issued by a commercial bank based on the private information of the borrowing enterprise, which is obtained from the long-term cooperation between the bank and the enterprise. Therefore, the pricing idea of relationship-based loan is mainly as follows: from the perspective of long-term cooperation with the enterprise, after comprehensively considers the costs and benefits of multiple cooperation with the enterprise, the related bank utilizes the excess economic profits (the relational rent) that are brought by the private information of the enterprise. Then through the adjustment of the interim period compensation between the current income and the rental income, achieve the price adjustment for SMEs' loans. The necessary premisesare that commercial banks have the ability to obtain private information of loaning enterprises, and also provide financial services to the loaning enterprisesbased on that in the long run.

\subsection{The Relationship Between the Pricing of Relationship-Based loans and That of Supply Chain Finance Instruments}

Supply chain finance instruments are financial products that provide financing services to the enterprises on the upstream and downstream in a supply chain. They are based on the real trade between enterprises in the supply chain, making full use of the flow and exchange of information flow, product flow and capital flow among the various links of the supply chain. There are similarities between supply chain finance instruments and relationship-based loans: First, they are both financial products that commercial banks provide to the SMEswith insufficient credit ratings and low collateral quality to alleviate their financing difficulties; Second, commercial banks carrying out supply chain finance services, with the information advantage of core enterprises, they can fully get the transaction information among enterprises in the whole process of "production-processing-sales" of the entire supply chain, and this information is within the commercial bank which is not available to outsiders; Third, commercial banks can maintain long-term cooperative relationships with upstream and downstream enterprises in the supply chain based on their own private information, and gradually form a monopoly on the pricing of services.

Therefore, in the process of providing supply chain finance services, commercial banks have the ability to obtain private information of enterprises in the supply chain and provide integrated financial services for the upstream and downstream enterprises. In the selection of pricing methods for supply chain finance instruments, commercial banks can learn from those for relationship-based loans. That is, provide financial products using the private information of the upstream and downstream enterprises in the supply chain obtained from long term corporation as the credit basis, anddivide the excess economic profits obtained from the following supply chain finance services which use the private information of the enterprise, then discount and add the present value to the pricing of the supply chain finance instruments. 


\subsection{The Differences Between the Pricing of Relationship-Based Loans and That of Supply Chain Finance Instruments}

Supply chain finance instruments are financing instruments that are collateralized by liquidity assets such as accounts receivable and inventory formed in the trade between upstream and downstream enterprises. The risk level exposed to commercial banks and the way to obtain private information are different from relationship-based loans. The pricing ideas are different in ways as follows.

Firstly, with the continuous development of the industrial economy, the competition between enterprises has gradually evolved into competition between different supply chains. Supply chain is a kind of enterprise structure model that integrates suppliers, producers and retailers in order to meet customer needs and comprehensively considers all aspects of production. And supply chain finance instruments arekind of financing service provided by commercial banks. When pricing supply chain finance instruments, commercial banks should not focus only on a single enterprise, considering the impact of excess returns that may be obtained by long-term cooperation and multiple transactions into instrument pricing, but should explore the impact of excess economic profit from long-term cooperation with a supply chain on instrument pricing. Because of the huge potential of the supply chain finance market, the competition among commercial banks is not to obtain the supply chain finance services of some enterprises in the supply chain, but to seize the monopoly right of each supply chain. It can be seen that the first difference is that the commercial banks' related enterprise has changed from a single SME to a supply chain, which is composed of a much larger scale of groups of enterprises. And the long-term cooperation between commercial banks and supply chain companies is characterized by multiple sales of supply chain products.

Secondly, the supply chain finance instruments commercial banks provide mainly includes prepayment financing, inventory financing and accounts receivable financing. The most important feature of the instrument isthat it is based on the real trade background between the upstream and downstream enterprises in the supply chain, and therefore is collateralized withliquid assets such as accounts receivable and inventory. The profit of commercial banks selling supply chain finance instruments depends mainly on the realization of trade and the fluctuation of the value of the collateral. Taking inventory financing instruments as an example, SMEs use the sales proceeds of pledged inventory as a source of repayment to obtain working capital for operations. When the financing enterprisespledge their inventory to commercial banks, banks are exposed to the risk of loss from inventory value fluctuations. The value of inventory affects the pricing of inventory financing instruments, and the risk caused by the random fluctuation of inventory value affects the financing company's repayment decision. Accordingly, the value fluctuation of inventory also affects commercial banks' decision whether to loan credit or not. Therefore, the second difference is that the private information of a company obtained by a commercial bank in the supply chain finance service is no longer the one that judges the true credit risk of the enterprise. Instead commercial banks evaluate the credit of an enterprise by learning about the real trading background between the upstream and downstream enterprises, evaluating the value of collateral accurately, and assessing whether fluctuations in collateral value meet their own requirements. And then decide whether to continue providing such instruments to companies in the supply chain. 


\section{The Pricing Model of Supply Chain Finance Instruments}

\subsection{Assumptions of the Model}

Seven assumptions are made to establish a pricing model for supply chain finance instruments. Assumption 1: The same kind of products produced by different SMEs in the supply chain are regarded as exactly the same product, and the corresponding supply chain finance instrumentsare regarded as the same instrument. Assumption 2: Commercial banks actually resell supply chain finance instrument after the last one has expired. However, to simplify the model, it is assumed that the reselling happens exactly at the same point when the last one expired. Assumption 3: The supply chain finance instrument market is a competitive market, in which there is no arbitrage opportunity, and the price of the instrument is the equilibrium price. Assumption 4: The fluctuationin the value of the collateral corresponding to the supply chain finance instruments conforms to the geometric Brownian motion, that isdST/ST=udt $+\sigma d w t$, where $u$ is the expected return rate, $\sigma$ is the volatility of instrument's price corresponded to the fluctuations in collateral value, anddwtis the standard Brownian movement. Assumption 5: Commercial banks can choose whether to continue selling certain types of supply chain finance instruments or not according to the fully master of the basic information of each trade between the upstream and downstream enterprises in the supply chain. Assumption 6: SMEs purchase supply chain finance instruments in one lump sum. Assumption 7: The company has a good operating condition during the purchase of supply chain finance instruments, and the financing demand is stable. When the financing prices from different banks are the same, the enterprise still select the original bank it borrowed from.

\subsection{Model Building}

In the process providing supply chain finance instruments, according to Assumption 1, commercial banks treat the same type of products produced by different enterprises as the same products in the same period. When different enterprises have financing needs, and purchase supply chain finance instruments with similar collateral from commercial banks, it is considered that commercial banks are repeatedly providing one type of supply chain finance instruments. Because the volatility of similar collaterals is affected by the same factors during the same period, the risk of value changes can be regarded as equal. According to Assumption 2 to 5, when the last supply chain finance instrument expires, the commercial bank can decide whether to continue to provide the instrument or whether to increase the price according to the value of the collateral at the time of expiration.

Similarly, if the value fluctuation of the collateral meets the basic lending requirements of commercial bank, the bank can distribute the excess economic profit generated by the next sale of the instrument to all enterprises that purchase it for a long time. By adding the excess economic profits of individual enterprise to the instrument, commercial bank can lower the price of the instrument, increase its competitiveness in providing supply chain finance instruments, and thus attracts more SMEs satisfying the borrowing conditions to purchase the instrument. According to Assumption 7, when the financing prices from different banks are the same, the enterprise chooses to borrow from the original bank. At this time, this commercial bank bears a lower risk of default and can provide more integrated financial services to the enterprise, so that the bank can obtain certain monopoly ability in the supply chain.

Therefore, when commercial bank grant credit to SMEs through supply chain finance, it acquires an excess economic profit option to expand the SME financial services. The underlying asset is the 
collateral corresponding to the supply chain finance instrument, the maturity price of the underlying asset in the option is the value of the collateral at the maturity date, and the executive price $\mathrm{K}$ is the time cost of the commercial bank's line of credit. The excess economic profit option follows several principles:

(1) When $S T \geq K$, commercial banks choose to exercise the option and continue selling such supply chain finance instruments.

(2) When $\mathrm{ST}<\mathrm{K}$, commercial bankswill not exercise the option.

It can be seen from the above that the excess economic profit option is an European call option of $\mathrm{T}$ years, and the commercial bank not only obtain the income I, but also obtain the option value C(S) of excess economic profit through the sales of supply chain finance instruments. Taking full account of the required returnRP and cost $\mathrm{C}$ of commercial banks, the pricing model of supply chain financial instruments is:

$$
I+\frac{1}{N} C(S) \geq C+R_{P}
$$

Where I is the income from salesof supply chain finance instruments, $\mathrm{N}$ is the number of enterprises in the supply chain that have long-term cooperation with commercial banks to purchase such supply chain finance instruments, $\mathrm{C}(\mathrm{S})$ is the value of option of commercial banks' excess economic profit, $\mathrm{C}$ is the cost of selling supply chain finance instruments, RPis the required return of commercial banks to sell supply chain finance instruments which is determined by the bank managers.

According to Assumption 3, the supply chain financial market is a competitive market, and supply chain instruments are financial services provided by commercial banks to all SMEs in the supply chain. Commercial banks do not have any information advantages. The two sides have mutual benefit and equality. In the game, the short-term target income of commercial banks should be equal to the cost that SMEs are willing to pay. Therefore, the price model of supply chain finance instrumentsin this paper should be adjusted to:

$$
I+\frac{1}{N} C(S)=C+R_{P}
$$

Through the building of the pricing model of supply chain finance instruments, it can be seen that the number of companies that have long-term cooperation with commercial banks $\mathrm{N}$ is positively related to the price of the instrument $i$, meaning that the lower the number of enterprises, the lower the price. In the early stage, when commercial banks first developed the supply chain finance business, lower product prices are conducive to attracting more customers. When the number of purchased enterprises continues to increase, product prices begin to rise. And when the commercial banks enter the mature stage in providing supply chain finance services, the quantity of cooperative enterprises tends to be saturated and the price becomes stable. At the same time, when commercial banks sell supply chain finance instruments, the bank's revenue may be lower than the cost of the supply chain finance instruments and also lower than the target income. The reason why commercial banks are willing to provide such intertemporal subsidies is that the preferential price can improve the competitiveness in supply chain finance services, obtain excess economic profits in the long-term cooperation with enterprises, and win the monopoly power of pricing of supply chain finance services in the future. 


\subsection{Decomposition of the Model}

\subsubsection{Sales Income of the Instruments}

The sales income of commercial banksin sale of supply chain finance instruments mainly include interest income I1, income from customer deposit I2, and income from related off-balance sheet activities I3, namely:

$$
I=I_{1}+I_{2}+I_{3}
$$

(1) The interest income I1 is commercial banks' main income in providing supply chain finance instruments, which can be calculated from the line of credit $\mathrm{A}$, the maturity $\mathrm{T}$, the price of the instrument $\mathrm{i}$, the commission fee $\mathrm{B}$, and the tax rate $\theta$.

$$
I_{1}=(A \times i \times T+B) \times(1-\theta)
$$

(2) The line of credit obtained by the SMEs through the purchase the supply chain finance instruments from commercial banks is generally not taken out at one time. Instead, SMEs usually open demand deposit account in the commercial bank to facilitate the transfer of funds. The income from customer's deposit I2 thus equals:

$$
I_{2}=\left[r_{1} \times\left(1-\beta_{1}-\beta_{2}\right) \times F+r_{2} \times\left(\beta_{1}+\beta_{2}\right) \times F\right] \times(1-\theta)
$$

Where $\mathrm{r} 1$ is the average rate of return on deposit, $\beta 1$ is the required reserve ratio, $\beta 2$ is the excess reserve ratio, $\mathrm{r} 2$ is the interest rate on reserves, and $\mathrm{F}$ is the average balance enterprise deposit in the bank during the borrowing period.

(3) The income from off-balance-sheet activities I3 is the income generated by commercial banks providing financial services to enterprises after selling supply chain finance instruments to SMEs. The financial services mainly include bank cards, settlement, guarantees, agency, asset management and consulting and so on. The calculation is as follows:

$$
I_{3}=\left(\sum_{k=1}^{9} \lambda_{k} \times n_{k}\right) \times(1-\theta)
$$

Where $\lambda \mathrm{k}$ is the price of the kth off-balance-sheet service provided by banks to their customers, nk is the times of which the kth service is provided.

\subsubsection{The Price of Excess Economic Profit Option}

From the above analysis, the excess economic profit option is a standard European call option. The payoff of the option at time $\mathrm{T}$ is:

$$
C(S)=\left\{\begin{array}{l}
S_{T}-K, S_{T} \geq K \\
0, S_{T}<K
\end{array}\right.
$$

According to the Black-Schole option pricing model, the price of the excess economic profit option is:

$$
C(S)=S_{0} N\left(d_{1}\right)-K e^{-r T} N\left(d_{2}\right)
$$

Where S0is the value of the underlying assets when the supply chain finance instrument is purchased, $\mathrm{K}$ is the strike price, $\mathrm{r}$ is the risk-free interest rate, $\mathrm{T}$ is the time to maturity of the credit in 
years, and $\mathrm{N}(\mathrm{x})$ is the probability that a random draw from a normal distribution will be less than $\mathrm{x}$.

$$
\begin{gathered}
d_{1}=\left[\ln S_{0} / K+\left(r+\frac{1}{2} \sigma^{2}\right) T\right] / \sigma \sqrt{T} \\
d_{2}=\left[\ln S_{0} / K+\left(r-\frac{1}{2} \sigma^{2}\right) T\right] / \sigma \sqrt{T} \\
K=S_{0} \delta(1+r)
\end{gathered}
$$

Where $\delta$ is the mortgage rate of supply chain finance instruments. Therefore, it can be found that the price of the excess economic profit option mainly depends on the initial value of the underlying assets $\mathrm{S} 0$, the risk-free interest rate $\mathrm{r}$, the mortgage rate $\delta$, the period of financing $\mathrm{T}$, and the volatility in the value of underlying assets $\sigma$. In addition to the volatility $\sigma$ that needs to be estimated, other variables are easy to be determined by commercial bank. The volatility in the value of the underlying assets measures its degree of fluctuation, and it is core in calculating the price of the option of the excess economic profit. By using asset valuation method to estimate the change in value of the collateral in case of default and not, the probability of default P is obtained. Suppose that the default occurs at the end of each period, then the standard deviation of the probability of default for each period is the volatility in the value of the underlying assets. See Figures 3.12 and 3.13 for details:

$$
\begin{gathered}
P=\frac{\text { Market value of the Collateral }}{\text { Book Value of the Collateral When Default }}-1 \\
\sigma=\sqrt{\frac{1}{T}\left[\sum_{K=1}^{T}\left(P_{K}-\bar{P}\right)^{2}\right]}
\end{gathered}
$$

\subsubsection{Cost of Providing Supply Chain Financial Instruments}

The cost of providing supply chain finance instruments mainly includes capital cost, operating cost and default loss cost, namely:

$$
C=C_{1}+C_{2}+C_{3}
$$

(1) Capital cost C1 refers to the cost of raising funds for providing supply chain finance instruments to upstream and downstream enterprises in a supply chain. Currently, commercial banks mainly use internal funds transfer pricing FTP to calculate the capital cost of loan. The calculation formula is as follows:

$$
C_{1}=A \times F T P \times T
$$

(2) Operating cost C2 includes two parts: fixed cost and variable cost. The fixed cost is composed of investigating fee of the credit status of the enterprise and the valuation fee of the underlying assets. The variable cost is the Selling, General, \& Administrative (SG\&A) expense in the process of providing the supply chain finance instruments.

$$
C_{2}=C_{f}+C_{v}
$$

Where Cf is the fixed cost, and $\mathrm{Cv}$ is the variable cost.

(3) Default loss cost C3 refers to the cost of default losses caused by the credit risk of the enterprise 
who could not repay on time. The formula is as follows:

$$
C_{1}=A \times P D \times L G D
$$

Where PD is the probability of default, and LGD is the loss given default.

\subsubsection{The Required Rate of Return on Providing Supply Chain Financial Instruments}

The required rate return of a commercial bank on providing supply chain finance instrument is the return that the bank must obtain to provide this service. Only if the return of a business reaches the bank's risk adjusted return on capital, RAROC, the bank will choose to carry out that business. Thus, the required rate of returnon providing supply chain finance instruments is calculated as follows:

$$
R_{P}=\min (R A R O C) \times E C
$$

Where EC is the economic capital used in providing supply chain finance instruments.

\section{Simulation Analysis}

Due to the liquidity problem, Company A wants to purchase the accounts receivable-type supply chain finance instruments from Bank B, collateralized with the accounts receivable of RMB11.27 million from Company C in 2016. After investigation and analysis by Bank B, Company A is a well-known manufacturing enterprise in the city. And the company has a relatively good operating status and strong repayment ability. Bank B's corporate credit rating system scores it 68, which is a rating of $\mathrm{BBB}$.

The debtor side of the accounts receivable, Company C, is a large listed company that operates supermarkets, building materials and department stores. It has established a long-term cooperative relationship with Bank B and is the core enterprise in the supply chain that Company $\mathrm{A}$ is in. Therefore, Bank B agreed to grant a loan of RMB9.016 million to Company A for twoyears of time with a mortgage rate of $80 \%$ of the underlying assets.

\subsection{Calculating the Price of the Instruments Using Loan Pricing Model of Commercial Banks}

Bank B currently uses the base rate plus markup methodto price loans to SMEs. Using the two-year loan benchmark rate of $4.75 \%$ announced by the People's Bank of China on February 29, 2016 as the base rate. The average cost rate of such loans calculated by the bank ERP system is $0.22 \%$, the credit risk premium of with the credit rating of $\mathrm{BBB}$ is $1.25 \%$, and the term premium of the 2-year short-term loans is 0 . The target profit margin of Bank B is $1.5 \%$. Thus, the price of the loan $\mathrm{i}=$ benchmark interest rate + floating level $=4.75 \%+0.22 \%+1.25 \%+1.5 \%=7.72 \%, 62.5 \%$ above the benchmark rate from People's Bank of China in the same period.

\subsection{Calculating the Price of the Instruments Using Supply Chain Finance Pricing Model}

The average daily balance of Company A's deposit at Bank B is estimated to be $2 \%$ of the loan, which is 1.8032 million yuan. The average rate of return on deposits $r 1$ is $4.6 \%$ in Bank $\mathrm{B}$, the required reserve ratio $\beta 1$ is $16.5 \%$. Regardless of the excess deposit reserve, the return on reserves $\mathrm{r} 2$ is $1.9 \%$. Bank B estimates that the off-balance-sheet services provided toCompany A are mainly payment settlement and bank card services. On average, the settlement service is provided once a day, with a charge of 30 yuan on average. And the bank card service has a fee of 50 yuan each time. Regardless of income from other services. Then, the income I from the sales of the receivables-type supply chain finance instruments is: 


$$
\begin{aligned}
& I_{1}=(A \times i \times T+B) \times(1-\theta) \\
&=(9016000 \times i \times 2) \times(1-5 \%)=17130400 i \\
& I_{2}=\left[r_{1} \times\left(1-\beta_{1}-\beta_{2}\right) \times F+r_{2} \times\left(\beta_{1}+\beta_{2}\right) \times F\right] \times(1-\theta) \\
&= {[4.6 \% \times(1-16.5 \%) \times 1803200+1.9 \% \times 16.5 \% \times 1803200] \times(1-5 \%) } \\
&= 71168.25 \\
& I_{3}=\left(\sum_{k=1}^{9} \lambda_{k} \times n_{k}\right) \times(1-\theta) \\
&=(365 \times 2 \times 30+365 \times 2 \times 50) \times(1-5 \%)=55480 \\
& I= 17130400 i+71168.25+55480 \\
&= 17130400 i+126648.25
\end{aligned}
$$

With reference to the coupon rate of bonds issued by China National Petroleum Corporation and Shanxi Natural Gas Co., Ltd., the coupon rate of 2-year bond is estimated to be 6\%, and pre-tax cost of debt is $3 \%$. The provision for bad accounts receivable of Company A is $10 \%$. Sothe market value and book value of the accounts receivable at the end of the period are as follows (see Table 1).

According to the calculation of Equation 3.12, the probability of default loss at the end of first year $\mathrm{P} 1$ is 0.1325 , and that ofthe second yearP2 is 0.2811 . The average probability of default loss in the two-year period 0.2068 . So, the value volatility of Company A's accounts receivable is:

$$
\begin{aligned}
& \sigma=\sqrt{\frac{1}{T}\left[\sum_{K=1}^{T}\left(P_{K}-\bar{P}\right)^{2}\right]} \\
& =\sqrt{\frac{1}{2}(0.1325-0.2068)^{2}+(0.2811-0.2068)^{2}} \\
& =0.0742
\end{aligned}
$$

The yield to maturity of three-year government bond which is $4 \%$ is used as the risk-free interest rate. The price of the European option $\mathrm{C}(\mathrm{S})$ is 2.6162 million yuan which is calculated by using Matlab. Bank B's two-year internal funds transfer price FTP is 4.55\%, then Bank B's capital cost C1 is 820,456 yuan. Bank B's investigation of the credit status of Company A and the assessing the market value of its accounts receivable cost 10,000 yuan. The SG\&A expenses incurred during the two years in providing the supply chain finance instruments are 40,000 yuan, and the operating cost of Bank B C2 is 50,000 yuan. The internal rating system of Bank B calculates the default probability and default loss rate of enterprises with different credit ratings for two years loan (See Table 2).

Table 1. The End Value of Accounts Receivable

\begin{tabular}{c|c|c}
\hline \multirow{2}{*}{ Year } & $\begin{array}{c}\text { Market Value of Accounts } \\
\text { Receivable (in million yuan) }\end{array}$ & $\begin{array}{c}\text { Book Value of Accounts } \\
\text { Receivable } \\
\text { (in million yuan) }\end{array}$ \\
\hline 1 & 11.4867 & 10.1430 \\
2 & 11.6951 & 9.1287 \\
\hline
\end{tabular}

Table 2. Bank B's Internal Rating of Default Probability and Default Loss Rate 


\begin{tabular}{c|c|c|c|c|c|c}
\hline Credit Rating & AAA & AA & A & BBB & BB & B \\
\hline Score & {$[90,100]$} & {$[80,90)$} & {$[70,80)$} & {$[60,70)$} & {$[50,60)$} & {$[40,50)$} \\
Default & $0 \%$ & $1.08 \%$ & $2.21 \%$ & $4.45 \%$ & $6.88 \%$ & $8.64 \%$ \\
$\begin{array}{c}\text { Probability } \\
\text { Default Loss } \\
\text { Rate }\end{array}$ & - & $46 \%$ & $28 \%$ & $36 \%$ & $42 \%$ & $38 \%$ \\
\hline
\end{tabular}

According to Table 2, Bank B's default loss cost $\mathrm{C}_{3}$ is as follows:

$$
\begin{aligned}
& C_{3}=A \times P D \times L G D \\
& =9016000 \times 4.45 \% \times 36 \% \\
& =144436.32
\end{aligned}
$$

Bank B's cost of providing the supply chain finance instruments to Company A, C, is:

$$
\begin{aligned}
& C=C_{1}+C_{2}+C_{3} \\
& =820456+50000+144436.32 \\
& =1464892.32
\end{aligned}
$$

The required rate of return on equity of Bank B is 16\%, and the risk adjusted return on capital (RAROC) is $16 \%$. The economic capital allocation coefficient of Company A, which is calculated by the economic capital allocation model of Bank B, is $8 \%$. The economic capital (EC) occupied by supply chain finance instruments is 721,280 yuan. And the required return (RP) for providing the accounts receivable type of financing product is 115,404.8 yuan.

There are eight SMEs in the upstream and downstream of the supply chain that have long-term cooperation with Bank B to purchase the accounts receivable type of financing products. The price at which Company A purchase the accounts receivable type of financing products from Bank B is $6.58 \%$, which can be obtained from the above formula 3.2. It is only $38.5 \%$ above benchmark loan interest rate for the same period. However, if calculated by the loan pricing model that Bank B is currently using, the price of the instrument is $7.72 \%$, which is $62.5 \%$ above the benchmark rate. Compared with the pricing method that does not consider the excess economic profit that may be generated by long-term cooperation between banks and enterprises, the pricing model of the supply chain finance instrument in this paper is more attractive, and the cost-benefit measurement is much clearer.

\section{Conclusion}

In the study of the pricing of supply chain finance instruments, this paper draws on the pricing ideas of relationship-based loans. It considers the long-term cooperation between commercial banks and SMEs in the upstream and downstream of supply chain and the characteristics of supply chain finance instruments. It takes the collateral of each type of supply chain instruments as the underlying assets, and then constructs the excess economic profit European call option when the commercial bank sells it in the next period. The excess economic profit is evenly distributed to the enterprises that purchase such products for a long time from the commercial bank, thereby the pricing model of supply chain finance instruments is built. The simulation analysis proves that the pricing model of the supply chain finance instrumentsbuilt in this paper is more attractive. Under the premise of ensuring the long-term target profit of commercial banks, the market share of the supply chain finance services is maximized, and the long-term competitive advantage is maintained.

With the continuous development of supply chain finance, the requirements for commercial banks 
on how to set reasonable instrument price are gradually improved. The pricing model of supply chain finance instruments built in this paper fully considers the characteristics of the instruments and cater to the development of supply chain finance services. To make the pricing model really plays a role and brings economic benefits to commercial banks, it also requires commercial banks to provide corresponding supporting measures.

\section{Acknowledgments}

This work was financially supported by the Philosophy and Social Science fund of Heilongjiang Province (Research on the relationship loan strategy of local Banks in Hei Longjiang province, 17JYE406)

\section{References}

[1] Berlin M, Mester L J. On the profitability and cost of Relationship lending, J. Journal of Banking and Finance ,1998, (22): 873-897.

[2] Arnoud W. A. Boot, Anjan V. Thakor. Can Relationship Banking Survive Competition? Journal of Finance, 2000,55(2):679-713.

[3] ADL Torre, MSM Pería, SL Schmukler. Bank involvement with SMEs: Beyond relationship lending, J. Journal of Banking \& Finance, 2010, (34): 2280-2293.

[4] Yeboah Asuamh Samne, Kumi Ernest, Jacob Baffour Awuah. What are small enterprises finance needs? J. European Journal of Business and Management ,2012,(04):196-206.

[5] Dai Guoqiang, Qian Lele. Relationship borrowing, bond financing and corporate loan cost -- based on the perspective of information and competition mechanism, J. Research of Auditing and economic, 2017, (05): 62-73.

[6] Guo Jiangshan. Relationship investment and development of community financial institutions - based on dynamic optimization analysis, J. Finance Forum, 2017,(12): 47-56 